\title{
KunstnerFørerens æstetiske visioner og nazismens totale kunst
}

\section{Kunstneren Hitler}

»I dag ved vi, at det ikke var tilfældigt, at Hitler ikke blev talt med som en af de utallige elever på Wiens kunstakademi. Han var nemlig udset til at påtage sig et større hverv end blot at blive endnu en god maler eller en god arkitekt. Talentet ud i malerkunsten er ikke et tilfældigt aspekt ved hans personlighed, men er tværtimod et træk der angår selve kernen af hans sind. Der eksisterer en direkte og uafviselig forbindelse mellem Førerens kunstneriske arbejde og hans store politiske værk «. ${ }^{1}$

Således stod der den 24. april 1936 i avisen Völkischer Beobachter i en artikel med titlen: »Kunst som basis for politikkens kreative kraft«. Artiklen handlede om kunstneren Adolf Hitler, og den fortalte i et bombastisk og skingert sprog historien om, hvorledes Hitler havde ernæret sig som kunstner i Wien og München i årene 1907 til 1913. Artiklen berettede om den svære tid, som Hitler måtte gå igennem i disse år, og om hvorledes akademierne i Wien ikke ville lade Hitler indskrive som studerende på kunst- og arkitekturskolerne. Der blev ikke gjort noget forsøg på at skjule, at Hitler ikke var blevet fundet egnet til at blive optaget på Wiens fornemme akademier. At Hitler dumpede til optagelsesprøven udtrykte ifølge Völkischer Beobachter intet negativt om Hitlers evner ud i det kunstneriske, men var tværtimod et klart udtryk for datidens dekadente og indspiste kunstmiljøer, der ikke havde været i stand til at få øje på Hitlers fantastiske kunstneriske kunnen. For selvom akademierne ikke havde fundet Hitler egnet til en egentlig uddannelse som maler, tegner eller arkitekt, mente artiklen, at der ingen tvivl var om hans status som kunstner. Han havde angiveligt endda store evner i den retning.

Omstændighederne omkring Adolf Hitlers kunstneriske karriere var i modsætning til hvad artiklen i Völkischer Beobachter giver udtryk for ganske ordinære og vidner mest af alt om manglende kunstneriske evner. ${ }^{2}$ Hitler 
kom til Wien i 1907 med intention om at realisere sig som kunstmaler, men måtte, da han var til optagelsesprøve på akademiet, sande, at hans egne forestillinger ikke havde hold i virkeligheden. Skuffet over afslaget fortsatte Hitler dog sin hidtidige tilværelse og betegnede sig stadig som kunstner. Hitler fortalte intet om afslaget til sin familie og venner. Han drev om i Wiens kunstmiljøer, gik i operaen og udkastede enorme projekter i hovedet og på papiret, som om intet var hændt. Det nærmeste Hitler kom til en egentlig kunstnerisk karriere var, når han fik sine få venner til at sælge de postkort med Wiener-motiver, som han yderst detaljeret malede med akvarelfarver.

Det var således en meget begrænset succes, Hitler oplevede som kunstner, hvis man i det hele taget kan tillade sig at karakterisere Hitler som kunstner. Som den store Hitler-biografist Joachim Fest skriver, så deltog Hitler da på heller ingen måde i de store kunstneriske landvindinger, som på det tidspunkt fandt sted i Wien og München. »Tidens kunstneriske opbrudsstemning« gik, som Fest skriver, »Hitler forbi. Wassily Kandinsky, Franz Marc eller Paul Klee, der boede i eller omkring Schwabing og gav malerkunsten en ny dimension, kom ikke til at betyde noget for Hitler. Han er stadig den samme, beskedne postkortkopist, der havde sine visioner, drømme og angstfølelser, som han altså ikke forstod at give kunstnerisk form. Med pedantisk omhu forvandlede han sine kompleksers og aggressioners spøgelsesverden til rene idyller, hvor hver mursten, hvert græsstrå, hver tagsten er fastholdt «. ${ }^{3}$ En egentlig praksis som kunstner udfoldede Hitler aldrig.

Men selvom Hitler således aldrig tog del i noget egentligt kunstnerisk miljø, deltog på udstillinger, eller lignende, så accepterede Hitler og det nazistiske regime i Tyskland ikke denne udgave af historien. Ifølge Hitler selv »ville han [hvis ikke den første Verdenskrig var kommet] måske...ja, højst sandsynligt være en af Tysklands betydeligste, måske den betydeligste arkitekt «. ${ }^{4}$ Som det officielt blev fremlagt, så ikke bare virkede Hitler som kunstner i årene op til den første verdenskrig, men han havde altid været kunstner, og det var hans kunstneriske evner og visioner, der gjorde ham selvskreven som fører af Tyskland. Som der står i artiklen i Völkischer Beobachter: »Hans kunstneriske aktivitet var ikke bare en tilfældig ungdomsgrille, er ikke bare en omvej som denne mands politiske geni har taget, men er selve hans kreative idés totalitet $«{ }^{5}$ Således forvandlede nazismens retorik Hitlers ikke videre vellykkede og spændende år i Wien og München til en mytisk begivenhed i sin egen historie. Hitlers anlæg for den kunstneriske aktivitet blev til en vigtig legitimation for hans virke i den nazistiske selvforståelse og propaganda. I Mein Kampf brugte Hitler således en del plads på at berette om, hvilken rolle kunst spillede for ham i udviklingen af den nationalsocialistiske 
forestillingsverden, og om hvorledes han begav sig til München for at drage næring ved kunstens kilder og for at udvikle sit »sensitive sind «. ${ }^{6}$

Selvom det er tvivlsomt, om man kan karakterisere Hitler som kunstner, er det netop, hvad det nationalsocialistiske regime gjorde, og de brugte denne karakteristik som legitimation for styret. Nazismen forvandlede årene, Hitler drev rundt i Wien og München, til en fantastisk begivenhed og et udtryk for begyndelsen på en særlig skæbne for Hitler og Tyskland, og derved gjorde den de fallerede kunstneriske aspirationer til en symbolsk begivenhed i produktionen af egen identitet. At Hitler selv flere gange i løbet af sin tid som Tysklands Fører faktisk indirekte indrømmede sin status som pseudokunstner, som da han fik Martin Bormann til at opkøbe alle de akvareller, der var tilgængelige for at forhindre, at de kom i offentlighedens lys, ændrer ikke ved det faktum, at det nazistiske regime iscenesatte Adolf Hitler som kunstner og derved legitimerede hans ret til at lede Tyskland. ${ }^{7}$

\section{Nazismens kunstdiktatur}

Den centrale rolle som kunst spillede i nazismens autoreferentielle mytologi, vil jeg forsøge at beskrive i det følgende. Jeg vil i mindre grad forsøge at skrive en historie om den kunst, der blev skabt under nazismen, endnu mindre foretage en decideret analyse af nazismen som et historisk fænomen, men derimod blot forsøge at foretage en bevægelse gennem den nazistiske myte, for derved at gengive de relationer og metaforiske forhold, der strukturerede forbindelsen mellem nazismen og kunst. I modsætning til de traditionelle analyser af forholdet mellem nazismen og kunst vil jeg forsøge at vise, hvorledes kunst var selve nazismens formål. ${ }^{8}$ Kunst var nazismens eksistensberettigelse, sådan som den selv opfattede det. Derfor er jeg mindre interesseret i at afsløre nazismen som grusom, 'falsk' eller et illusorisk spektakel, end jeg er $i$ at tage nazismen alvorligt for at få greb om dens specielle attraktivitet og energi, der er nært knyttet sammen med dens forestillinger om kunst. For med kunstner-diktatoren i spidsen for det mytiske arbejdsfællesskab skulle ideen om den udvalgte race realiseres i formen og derved fungere som den proces, hvormed racens ånd formede sin egen krop i al sin renhed. Kunst, forstået som formgivning, var det laboratorium, i hvilket det nazistiske fællesskab skulle skabes. Fordi den nazistiske ideologi var usikker og ustabil, tog nazismen tilflugt i en form for æstetisk og kunstnerisk overkill. ${ }^{9}$ Jeg vil således undersøge aspekter af nazismens symbolske diskurs, som den manifesterede sig gennem taler, tekster, billeder og ritualer, som en 'tekst', der berettede nazismens historie. ${ }^{10}$ Jeg leder med andre ord efter bestemte 
troper i analysen af nazismen. I analysen har jeg undersøgt tilstedeværelsen af æstetiske referencer, da disse var centrale i konstruktionen af nazismen. ${ }^{11}$

I denne forbindelse er det selvfølgeligt vigtigt at huske på, hvad æstetik egentlig betød for nazismen, hvad der gjorde æstetikken til privilegeret støbeform for nazismens fællesskab. Som Susan Buck-Morss har gjort opmærksom på, i forlængelse af Terry Eagletons The Ideology of the Aesthetic, så var æstetik oprindeligt en diskurs om kroppen og havde ikke relation til kunst som sådan. ${ }^{12}$ Estetik eller aisthitikos refererede til noget, man kunne føle med sanserne og var således knyttet til en kropslig erfaring. I løbet af det 17 . og 18. århundrede skete der imidlertid en forvandling af æstetikken, som fra da af begyndte at koncentrere sig om kulturelle artefakter og primært fik betydning i en filosofisk diskussion om kunst, som samtidigt blev autonom og adskilt fra livspraksis. Forbindelsen med kunst resulterede i, at æstetikken idet kunsten i æsteticismen afviste ethvert forhold til kunsteksterne forhold og forsøgte at få kunstens institutionelle status til at falde sammen med enkeltværkernes indhold i en ekstremt formaliserende kunst ${ }^{13}$ - mistede sin forbindelse med kroppen. Estetik i betydningen af den sanselige kropserfaring blev negeret til fordel for æstetik som betegnelse for værkets formelle aspekter. I æsteticismen blev enhver henvisning til sanserne og et 'ekstrakunstnerisk' indhold afvist som værende irrelevant for den kunstneriske praksis, som qua autonom ikke skulle følge andet end egne internt definerede regler og ikke skulle interessere sig for andet end skabelsesprocessen, hvor kunstneren skabte verden på ny og således totalt beherskede sit materiale. Denne situation, hvor kunstneren skaber sig selv, og hvor æstetik er skilt fra sanserne, udgjorde en form for mulighedsbetingelse for nazismens æstetiserede politik, som overfaldt og overrumplede sanserne på en sådan måde, at den moderne postauratiske perception subsumeredes under en karismatisk magts former. Nazismens æstetik var anæstetisk, i begrebets oprindelige mening, fordi den udraderede sanserne og underordnede kroppen KunstnerFørerens suveræne beslutninger. ${ }^{14}$ KunstnerFøreren Hitler skabte Tyskland som en suveræn kunstner skaber et kunstværk uden interesse for andet end ekstrapoleringen af en perfekt form.

Jeg vil i det følgende se på, gennem hvilke processer nazismen skabte historien om sig selv og vil således undersøge forholdet mellem repræsentation og magt, som det kom til udtryk i nazismens meget heterogene 'tekst'. De historier, som nazismen fortalte om sig selv, var en måde at skabe magt på, at stifte autoritet på. Ved at repræsentere magt skabes der magt, og derfor var nazismen ustandseligt optaget af at fortælle om sin magt. ${ }^{15}$ Magten skulle hele tiden iscenesættes for at skabes. Magt kan kun opretholdes gennem synlige tegn og derfor var nazismens kunst, ritualer, myter og taler nødvendige for 
ikke blot at legitimere nazismens politik, men simpelthen for at konstruere nazismens magt og dens politiske visioner.

Når det nazistiske regime vælger at fremstille Hitler som kunstner, er det ikke uden konsekvenser for dets adfærd og selvforståelse. Hvorvidt fremkonstruktionen var rigtig eller forkert, er i denne sammenhæng mindre vigtigt, end at den faktisk aftegnede og guidede nazismens handlinger, konstruerede en horisont for nazismen, skabte et verdensbillede, hvor nazismens handlinger gav mening. Repræsentationen af Hitler som kunstner skabte nye meninger, som påvirkede nazismens selvforståelse, dens fremtidige udviklinger og dens ansigt udadtil. De forskellige iscenesættelser af KunstnerFøreren gennem taler, tekster, ritualer og myter var fundamentale for konstruktionen af nazismens magt og overskred langt deres karakter som blot og bar politisk legitimation.

Jeg vil nærme mig forholdet mellem nazismen og kunst gennem en analyse af en tegning. Forholdet er, som det hurtigt bliver klart, ikke bare resultatet af en bestialsk stats propagandistiske brug af kunst i en politisk tjeneste, eller at kunst fungerede som en art skalkeskjul for en skånselsløs brug af magt. Det var snarere sådan, at kunst var nazismens eksistensberettigelse, at kunst var la raison d'être for dets diktatur. Hvis vi kun opfatter forholdet mellem nazismen og kunst som et spørgsmål om at erkende, at nazismen pressede kunsten ind i et bestialsk styres tjeneste for at markedsføre forbrydelser under et lag skinnende fernis, overser vi den paradigmatiske rolle, som kunst spillede i den nazistiske forestillingsverden. Samtidig gør vi os skyldige i at overvurdere kunstens humanitære egenskaber og idealisere kunst som en beskytter af politisk frihed. ${ }^{16}$ Kunst var ikke et genstridigt gidsel i nazismens klør, men var selve målet for nazismens diktatur, der præsenterede sig som geniets diktatur.

\section{Den tyske nation som kunstnerisk materiale}

Den tyske tegner Thomas Garvens præsenterede i 1933 en tegning i tidsskriftet Kladderadatasch med titlen »Tysklands skulptør «. ${ }^{17}$ På fire billeder ser man Adolf Hitler udfolde sine kunstneriske evner. På det første billede ser vi Hitler med misbilligelse betragte en skulptur, skabt af en bebrillet, slunken jødisk kunstner. Skulpturen forestiller en uharmonisk masse af mennesker, der strides og kæmper i et virvar af arme og ben. På det næste billede retter Hitler et knusende slag mod den kaotiske skulptur til stor bestyrtelse for den jødiske kunstner, der øjensynligt farer sammen konfronteret med Hitlers angreb og handlekraft. På det tredje billede ser vi Hitler i fuld gang med at for- 
me og modellere den knuste skulptur, han bearbejder og ælter materialet, og på det sidste billede færdiggør Hitler en stor skulptur i klassisk græsk stil. Således skulle den nazistiske kunst være en mere ophøjet kunst, der skulle forene det virkelige og det ideelle i en total kunst, der transformerede beskuerne. Meningen med tegningerne er ikke til at tage fejl af: Hitler skaber en strålende figur ud af en disharmonisk masse. Han former og udgrænser det kaotiske og uoverskuelige og skaber én eneste figur, en kolos, der står stolt og firskåren i modsætning til den jødiske kunstners skulptur, der afbilder et sammenfiltret kaos af menneskedele. Som en moderne Michelangelo finder Hitler ind til materialets iboende form og lader det komme til syne, befrier det. Når kunstneren Hitler kommer til magten, forlener han massen med enhed og stolthed, egenskaber som Tyskland mistede ved nederlaget i Den Første Verdenskrig.

Garvens tegninger supplerer med oplysninger om det nazistiske regime og dets verdensbillede. Udover at være en billedliggørelse af den enhed, som det tyske rige proklamerede - „Ein Reich, ein Volk, ein Führer« - er tegningerne en illustration af det forhold, som Joseph Goebbels gav udtryk for i et brev til Wilhelm Furtwängler, at nazismens ledere var en slags kunstnere: Vi, som skaber den moderne tyske politik, føler os som kunstneriske mennesker, hvis vigtigste opgave det er at skabe et formgivende billede af folket ud af massens grove materiale«. ${ }^{18}$ Det nazistiske regimes ledere så sig selv som kunstnere og så folkemassen som det materiale, de med voldsom passion skulle forme. Som Jean-Joseph Goux skriver, var »kunstnerens kreative kraft den samme som politikerens kreative kraft ${ }^{19}$ for det nazistiske regime. Den passion, som ifølge Goebbels karakteriserede kunstneren, var et konstitutivt træk ved det nazistiske politiske geni, hvori passionen smeltede sammen med udøvelsen af magt. Den forbindelse som tegningerne viser mellem kunst og politik hos Hitler, og som Goebbels henviser til i sit brev, var langt mere end blot et resultat af en pittoresk, bogstavelig prætention, og der er ikke blot tale om en forbindelse som i ny og næ blev draget frem. For det nazistiske regime var forbindelsen mellem kunst og politik selve nerven i deres oppumpede nazistiske krop, og det var denne forbindelse, der styrede nazismens forestillinger om politikerens forhold til befolkningen. ${ }^{20}{ } \mathrm{Og}$ hvis Gud måske i dag lader sangerne og digterne være stridsmænd, så har han også givet stridsmændene de bygmestre, der vil sørge for, at denne kamps udfald får sin uforgængelige bekræftelse i en enestående stor kunst. Denne stat skal ikke være en magt uden kultur og ikke en kraft uden skønhed. ¿1 $^{21}$ 

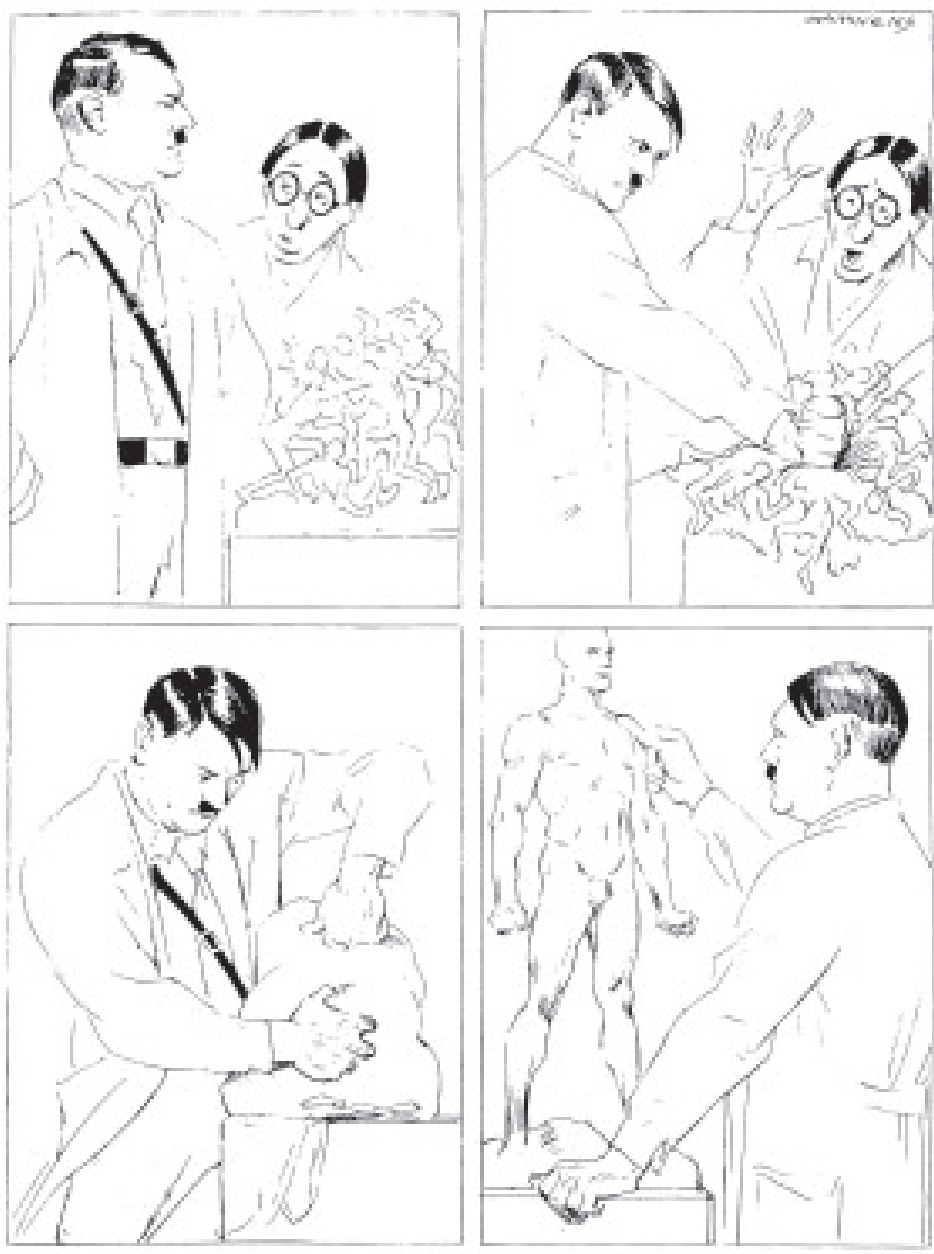

\section{Formgivning af massen}

Estetik var for Hitler den horisont, indenfor hvilken han forstod og udfoldede sin eksistens. Livet var en marmorblok, han skulle forvandle til et kunstværk. Dette på en gang kunstneriske og politiske arbejde var for Hitler »en til fanatisme forpligtende mission ${ }^{22}{ }^{22}$ som der ingen modsætninger var i. Kunst og politik skulle nemlig leve op til den samme standard: produktionen af en stærk, velformet og evig krop. Gennem æstetik kunne Hitler og det nazistiske regime forkaste den traditionelle bureaukratiske politikerrolle og revitalisere den, og derved blev det muligt at forestille sig virkeligheden som en kunstnerisk produktion, der var underlagt KunstnerFørerens absolutte vilje. Folket som masse var objekt for den nazistiske kunstner-politiker, og det var 
nødvendigt at gøre front mod 'den molekylære masse', der hvert øjeblik kunne implodere. ${ }^{23}$ Den nazistiske leder skulle ikke identificere sig med massen, men skulle adskille sig fra den for at bemestre den som en kunstner, der hæver sig op over sit materiale. »Genier af usædvanlig art [...] tillader intet hensyn til den normale menneskehed «. ${ }^{24}$ Det tilhørsforhold som eksisterede mellem lederen og hans folk, kunstneren og hans marmorblok, skulle overvindes, således at massen kunne blive underlagt lederens vilje, kunne være objekt for lederens æstetiske syn. Hitler har i Garvens tegninger frigjort sig fra massen, har hævet sig op over den for bedre at kunne kontrollere og forme den i overensstemmelse med sine storstilede planer.

Hitler konciperede den tyske befolkning i overensstemmelse med det sene 1900-tals elitære masseteorier, der, konfronteret med den hastige accelererende industrielle og urbane udviklings medfølgende usikkerhed, forsøgte at etablere videnskabelige regler for menneskelig adfærd, og i særdeleshed for 'massen', der blev udnævnt til den primære årsag til social urolighed, idet folk, ifølge teoretikere som Gustave Le Bon og Gabriel Tarde, opførte sig uansvarligt og irrationelt, når de var i en gruppe. ${ }^{25}$ Fordi massen var kendetegnet ved en følelsesladet og irrationel adfærd, skulle de ikke inkluderes i et repræsentativt, parlamentarisk demokrati, men skulle bemestres af en leder ved hjælp af myter og teatralske forestillinger. ${ }^{26}$ "Massen trænger til et idol«, som Hitler sagde. ${ }^{27}$ Massen var som en kæmpe hysterisk kvinde, man ikke kunne appellere til med fornuften, men kun med følelser. „Folket er for størstedelen så feminint anlagt og indstillet, at det ikke så meget er nøgterne overvejelse som følelsesmæssig indstilling, der bestemmer dets tanker og handlinger. $\aleph^{28}$ Hitlers forestillinger om massen som feminin passede fint med hans æstetiske visioner af politikken, idet den feminine masse på samme måde som kunstnerens passive og modtagelige materiale skulle domineres og tvinges i form. ${ }^{29}$ Den kunstneriske masse havde brug for at blive befriet fra sin marmorblok, på samme måde som den feminine masse havde brug for at blive bemestret af en mandlig leder. "Ligesom kvinder, hvis sjælelige følelser mindre bestemmes af den abstrakte fornufts grunde end af en ubestemmelig, følelsesmæssig længsel efter en supplerende kraft, og som derfor foretrækker at bøje sig for den stærke leder frem for at beherske svæklingen, således elsker massen også herskeren højere end den, der beder« ${ }^{30}$ Kvinder skulle ifølge Hitler ikke blande sig i det politiske liv og var kun af interesse, når de fødte nye tyskere. De var ikke egnede til at skabe kunst - »endelig strikker de tyske kvinder igen ${ }^{31}{ }^{31}$ sagde Hitler efter magtovertagelsen - og var derfor par excellence det materiale, hvormed den mandlige fører skulle skabe en sublim politisk form. Ex nihilo frembragte Hitler sit tusindårsrige, idet han nægtede den feminine masse indflydelse og formede massen efter æstetiske idealer. 
Den selvskabende, omnipotente Hitler havde således fuld kontrol over sit projekt og »bedre end ved en jomfrufødsel, frembringer det moderne menneske [Hitler], homo autotelus, bogstaveligt sig selv. $\ll^{32}$

\section{KunstnerFørerens vilje}

Garvens tegninger vidner om, at med Hitler er den voldsomhed, hvormed kunstneren bemestrer sit materiale, blevet den politiske leders dyd. En voldsomhed som i Garvens tegninger umiddelbart kun rettes mod den jødiske kunstners skulptur, der repræsenterede det parlamentariske kaos i Weimarrepublikken. Som det sker i tegningerne ville det nazistiske regime ødelægge alt, hvad Weimar-republikken stod for og havde fået opbygget, og det med den samme voldsomhed, som vi ser repræsenteret i tegningerne, hvor det dog kun er en repræsentation af den tyske befolkning, som udsættes for Hitlers kunstneriske vilje. Det er dog værd at lægge mærke til, at den jødiske kunstner forsvinder ud af tegningerne fra og med det tredje billede, og således lider samme skæbne som hans skulptur: han udsættes for den kunstneriske viljes kraft og ekskluderes. Garvens anticiperede således i sine tegninger den skæbne, som det nazistiske diktatur havde reserveret til sine fjender og modstandere. ${ }^{33}$ En skæbne som altså hang nøje sammen med det, tegningerne viser: nemlig at Hitler havde formået at overføre sine kunstneriske overbevisninger til den politiske sfære, og at massen var førerens kunstneriske medium. Tegningerne viser, at Hitlers syn på de sociale relationer var gennemsyrede af æstetiske konceptioner, der muliggjorde en viljens og kraftens politik i den skønne forms tjeneste. Som den store kunstner skulle Hitler ikke lade sig regulere af andet end æstetiske hensyn. »De største kunstnere og bygmestre har lov til at se stort på deres smålige samtids kritiske bemærkninger. Deres værker bliver endegyldigt bedømt og påskønnet af århundreder og ikke af små hverdagsindsigters ytringer «. ${ }^{34}$

Garvens karikaturtegning vil ofte umiddelbart blive dechifreret af nutidens øjne som en samtidig kritik af det nazistiske regimes vanvittige diktator, og måden hvorpå han forholdt sig til den moderne kunst. Det er imidlertid spørgsmålet, om ikke snarere tegningen registrerede det Tredje Riges forestillinger om kunst. Tegningen vidner ganske vist om det had, som Hitler havde til den moderne kunst, og den behandling han ønskede at udsætte den moderne kunst og Tyskland for. Men tegningen er måske nok mere neutralt registrerende end decideret kritisk og satirisk. En tolkning der fokuserer på det 'propagandistiske' aspekt - tegningerne er løgnagtige, idet de skjuler, hvad der faktisk skete i Tyskland - formår ligeledes ikke andet end at afmy- 
stificere nazismen. Den formår ikke at analysere, hvilken betydning kunst spillede i den nazistiske mytologi, og hvorledes en sådan betydning blev muliggjort historisk. En sådan fortolkning vil ganske vist være i tråd med den generelle historiografi, der analyserer forholdet mellem nazisme og kunst efter en afmystificerende dagsorden, der tildeler en propagandistisk make upmanøvre centrum i analysen af den nazistiske kunst- og selvforståelse. I stedet skulle vi måske antage, at Garvens tegning passede ganske nøje til Hitlers egne forestillinger og således udtrykker Hitlers egen 'kunstneriske' drøm. Mellem KunstnerFørerens fingre fik det tyske folk endelig den form, der legitimerede Hitlers magt. "Som en statue står han - allerede vokset ud af den jordiske dimension ${ }^{35}$ En form som svarede ganske nøje til den klassiske antikke form, som det tyske folks ånd ifølge Hitler var arving til og indhold i. Hitler vækkede masserne og "gjorde dem til sit værktøj«i skabelsen af sit og Tysklands mesterværk. ${ }^{36}$ Således fandt kunstneren Hitler sig retfærdiggjort i og gennem sit kunstværk. »Jeg har altid haft den følelse [...] at mennesket, så længe han er i live, skal længes efter dem, han har formet sit liv sammen med. Hvad ville mit liv være uden jer! At I engang har fundet mig, og at I har troet på mig, har givet jeres liv en ny betydning og en ny opgave! « ${ }^{37}$

\section{Kropspolitik}

Et af hovedelementerne i den nazistiske mytologi var identifikationen af Hitler med Tyskland:»Ein Reich, ein Volk, ein Führer«var løsenet. Selvom det nazistiske parti var en vigtig komponent i den nazistiske mytologi, og det Tyske Rige på sin vis ikke skulle være andet end partiet, var det lederen og føreren Hitler, der gjorde det muligt for folket og racen at smelte sammen til én krop. Som Ian Kershaw har vist i The Hitler Myth, var Hitler ualmindeligt populær, selv når det nazistiske parti ikke var det, og det gik mindre godt med at løse de sociale problemer i Tyskland. "Det er blevet foreslået at da hans [Hitlers] popularitet var højest, støttede ni ud af ti tyskere Hitler, troede ni ud af ti tyskere på Føreren. Lige meget hvilke kvalifikationer, en sådan påstand kræver, så er det sikkert at opbakningen til det nazistiske parti aldrig nåede sådanne højder [...] Jublen over Hitler rakte langt ud over dem, som opfattede sig selv som nazister ${ }^{38}{ }^{3}$ Det nazistiske parti var et parti, der skulle løse de sociale problemer kunstnerisk, ${ }^{39}$ men alene kunne partiet ikke udgøre det libidinale objekt, der skulle binde den feminine masse sammen og formgive dens formløse krop. Det kunne kun føreren Hitler. Nazismen identificerede Hitler med Tyskland direkte, fysisk, fordi Hitler var skabt tysk. Denne identifikation arbejdede Hitler bevidst på at synliggøre gennem et stort reper- 
toire af falliske gestus og dynamiske udtryk. ${ }^{40}$ Der blev ikke sparet på midlerne $\mathrm{i}$ iscenesættelsen af Hitler som en skabning med guddommelig status, der fløj rundt over Tyskland og blot landede fra tid til anden for at udstede dekreter og give massen udløsning, som vi kan forvisse os om ved et gensyn med Leni Riefenstahl Triumph des Willens. »I den skyggefulde himmel dukker et fly op, det paradigmatiske modernistiske befordringsmiddel, som bærer den guddommelige leders krop, garanten for national opstandelse, hvis ankomst på jorden medfører den mirakuløse inkarnation af den triumferende vilje. Fra da af overvindes historien, og det jublende folk glæder sig i et indløst nu skabt af den fysiske tilstedeværelse af den synlige frelsermand. ${ }^{41}$ Billeder af Hitler som nationens førstemand eller stjerne blev bogstaveligt talt produceret i millionvis. »Det er en videnskabelig, moderne reklameorganisation som har givet det hitlerske parti sin formidable evne til udvidelse. Du finder naturligvis alle dagens helte på postkort, og hvis du ønsker et portræt af Føreren, vil du have svært ved at vælge. Der er i sort-hvid, i farver, i alle formater, med glas, indrammet i guld. I mere end en time har denne trofaste dame [...] forelsket betragtet de forskellige rammer, som hun kan vælge imellem uden at kunne bestemme sig«. ${ }^{42}$ Guérins formuleringer illustrerer, hvorledes mennesker blev deltagere i en autoritær pagt som tilskuere, hvis syn var fikseret på førerens omnipræsente ikon. Den meget omtalte følelse af umiddelbar deltagelse i alt hvad der foregik i det Tredje Rige, som nazismen genskabte for den almindelige mand, var mindre en aktiv deltagelse som sådan og mere et direkte forhold til Gud (=Hitler). Det var gennem førerens feticherede krop, at den enkelte tysker blev bundet til partiet og racen.

Ifølge den franske filosof Claude Lefort er den proces, hvormed Hitlers feticherede krop befæster individets binding til racen, karakteristisk for totalitarismens forsøg på at løse demokratiets paradoksale 'magtløshed'. ${ }^{43}$ Det der kendetegner demokratiet er, at ved at halshugge kongen, som det skete i den franske revolution, så at sige afskaffer den imaginære enhed, som kongen tidligere tilbød samfundet. Lefort opererer således med tre etaper i sin teori om subjekters libidinale relationer til samfundets ledere i de moderne vestlige samfund. I den første etape er det kongen fra l'ancien régime, som er det libidinale objekt. I karakteristikken af kongen som både dødelig og udødelig fortsætter Lefort Ernst Kantorowiczs arbejde, som det kom til udtryk i dennes magistrale The King'sTwo Bodies. A Study in Medieval Political Theology. ${ }^{44}$ Kantorowicz undersøgte i denne bog monarkiets juridiske rødder, og viste, hvorledes den vestlige kristne tradition udstyrede kongen med en dobbelt natur: menneskelig og guddommelig på en gang. Takket være en distinktion mellem denne dobbelte natur, kongens to kroppe, blev det absolutistiske monarki helliggjort. Kongen havde på den ene side en forgængelig krop som 
alle andre mennesker, og på den anden side havde kongen en udødelig krop, hans politiske krop, der levede videre efter at den person, der inkarnerede den, døde. I forlængelse af denne dobbelte krop skulle kongen agere både 'revolutionerende' og 'konserverende'. Kongen skulle være revolutionerende, forstået som i stand til at sætte sin vilje igennem og bruge vold, overfor folket og nationen, og i særdeleshed overfor nationens fjender. Samtidig skulle han være konserverende for at opretholde og sikre den transcendentale idés kontinuitet, idéen om monarkiet og dets arvefølge. Monarkiet blev således konciperet som en krop, som kongen både udgør og dirigerer i egenskab af at være dets hoved.

Idet den demokratiske revolution halshugger kongen, halshugger den også sin egen kropspolitik, og den tidligere imaginære sammenhæng fragmenteres. Med demokratiet sker det, at "magtens rum bliver et tomt rum «, ${ }^{45}$ det er ikke længere muligt at besætte eller udfylde det. Efter halshugningen af kongen er det ikke længere muligt at udtrykke den symbolske 'eksternalitet' i én person. Revolutionen markerer og synliggør således forskellen mellem magthaveren og magtens sted, idet den efter kongens halshugning ikke indsætter en ny konge eller leder, men holder magtens sted åbent og tomt. Der er ikke længere én person, som repræsenterer det hele eller forvalter den symbolske magt. Det er ikke personen men den politiske scene, der så at sige er forlenet med magt og derved blotlægges selve processen, hvorved magten skabes. Repræsentationen af samfundets helhed udsættes for en 'desinkorporation' i demokratiet. Fra nu af må magthaveren nøjes med at cirkulere omkring magtens sted og agere gennem en diskurs, der markerer forskellen mellem udsigelse og symbolsk position. Den enhed og mening, som monarkiets absolutte basis var udstyret med gennem den transcendente grundlæggelse kongen gav krop til, faldt bort med revolutionen, og magten og den sociale enhed lå nu hos folket. Den demokratiske revolution resulterede i at samfundets mening blev usikker og blev et objekt for debat. Usikkerheden om samfundets orden autoriserede demokratisk debat.

Nazismens totalitarisme dukkede ifølge Lefort frem som et forsøg på at udfylde magtens paradoksalt tomme sted. »Gennem en omvending af den demokratiske logik [...] holder magten op med at betegne et tomt rum, den materialiseres i et organ (eller i det mindste et individ), som tilsyneladende er i stand til at samle hele samfundets magt «. ${ }^{46}$ Monarkiets metaforik med den dobbelte krop genrejses gennem »Egokrat«-figuren, der garanterer »billedet af Ét-folket «. ${ }^{47}$ Nazismen reagerer mod demokratiets uvished ved at etablere en ny symbolsk magt. Ved hjælp af oprindeligt demokratiske forestillinger som 'folket' negerer nazismen demokratiet i jagten på konkret totalisering. Den ødelægger demokratiets scene og debat til fordel for en identifikationslogik 
centreret om føreren. Føreren Hitler repræsenterer ikke nogen eller noget i almindelig forstand, han er identisk med folket og med det Tredje Rige. Dermed skabes der et fuldstændigt homogent samfund uden konflikter og debat, for forskel kan ikke repræsenteres. Konflikter forvandles til undtagelser eller anomalier, der intet har med det Tredje Rige at gøre, som jøderne. »Billedet af Ét-folket« afhænger således af disse to ting: »den sociale krops fuldstændighed « og "produktionen af fjenden $« .{ }^{48}$

\section{Guddommens synlige inkarnation}

Ved hjælp af Leforts og Kantorowiczs analyser af kongens 'mystiske krop', troen på hans evige natur - i kraft af hvilken den royale dignitas overlever sin bærers fysiske person - kan vi undersøge den komplicerede forestilling, som nazismen havde om kunst, og den rolle som Hitler spillede i den. Kantorowiczs analyser viser nemlig den religiøse natur i såvel monarkiets legitimation, som i den nazistiske mytologi, hvor det tyske folks drøm om sin tidligere tids kunst fik krop gennem en quasi-religiøs drøm. Den kristne politiske teologi brugte forestillingen om Kristi mystiske krop - menneskelig og guddommelig - til at skabe en kontinuitet i statens corpus morale et politicum, for derved at sikre en stabil politisk orden. Nazismen overtog forestillingen om kongens dobbelte krop, og derfor kunne Hitler arbejde med folket som sit materiale for at bevare det selv samme folks form og ånd. Hitler udfoldede sin guddommelige frihed og kreativitet på det folk, hvis ånd var legitimation for hans autoritet. Men i modsætning til monarkiet, hvor den royale autoritet overlevede sine repræsentanter, var Hitlers magt knyttet direkte til hans krop, og således blev han dobbelt hellig. Ingen kunne for alvor efterfølge Hitler som Tysklands fører, for Tyskland var Hitler, som han var folket: „Ein Reich, ein Volk, ein Führer«. Der blev da også gjort alt for ikke at lade befolkningen vide, at Hitler i al hemmelighed så forskellige kvinder, for selv Hitlers jordiske krop var hellig og måtte ikke besudles. Massen var hans »eneste brud «. ${ }^{49}$

Men nazismen benyttede sig ikke blot af forskellige religiøse idéer, men forsøgte snarere selv at fungere som en religion. Som Jean-Joseph Goux skriver: „Af en næsten ord for ord ombytning af de eksisterende religiøse læresætninger fremstår en ny religion, en ny og anden kirke. Således bliver Min Kamp [...] til 'den helligste af alle bøger for tyskerne og følgelig for Gud'. Bogens forfatter, Føreren, 'er den nye åbenbarings budbringer’ " ${ }^{50}$ Hitlers rolle i det nazistiske verdensbillede havde en bogstavelig religiøs funktion, hvor hans tilsynekomst var identisk med realiseringen af det evige rige. Hit- 
ler var den synlige inkarnation af folkets guddommelige ånd, og på den måde forblev idéen om inkarnation - en idé som er selve hjørnestenen i den kristne tro - uforandret i det nazistiske regime. Hitler udnævnte sig selv til »førerpaven ${ }^{51}{ }^{51}$ men retfærdiggjorde sin spirituelle suverænitet under henvisning til sin kunstneriske kreativitet, der var båret oppe af og inspireret af das Volksgeist. Med denne legitimation fuldendte han Julius Langbehns profetier om en frelsers komme; en frelser der ville være "på én gang en kejser og kunstner«. ${ }^{52}$

På samme måde som kristendommen var forankret i troen om frelse gennem guddommens synlige inkarnation, var den nazistiske religion det. Derfor kunne Hitler tillade sig at postulere, at paradiset og det evige rige ikke blot var en drøm og et fantasme, men var begyndt med den nye messias' tilsynekomst. Som Fest skriver: »I Hitler fandt dette fører-flok-forhold, der inkorporerede alle, sin ophøjede pseudoreligiøse fuldbyrdelse. En eksalteret kirkens mand fra Thüringen drev det endda så vidt som til at sige: 'Kristus er kommet til os gennem Hitler' ${ }^{53}$ Et evighedens rige som ikke blot var en politisk og religiøs genfødsel for det tyske folk, men i lige så høj grad havde karakter af en kunstnerisk renæssance. Evighedens rige begyndte, idet det tyske folk skabte stor kunst igen. Den tyske nation, der var blevet frarøvet sin kunst og var blevet såret på sin sjæl, var tynget af en gæld, som Hitler ophævede gennem den synlige produktion af stor tysk kunst. Hitler gav tyskerne grund til at elske sig selv, og så længe dette skete, elskede de ham. Den proces, hvori Hitler udfoldede sin kunstnerisk vilje, fungerede som et indvielsesritual, hvor folket kunne få et glimt af den kommende ariske verden. I den kunstneriske skabelse skulle hver ny generation sutureres ind i det Tredje Rige. ${ }^{54}$

\section{Folkets drøm}

Opgaven med at skabe det tyske folks form og ånd og give tyskerne en fornemmelse af deres eksistens blandede sig med nødvendigheden af at skabe folkets drøm som en synlig produktion, en produktion af Volksgeist som nazisterne identificerede med kultur. »Viljen triumferer, når den bliver synlig“, som Russell Berman skriver. ${ }^{55}$ Det nazistiske regime byggede videre på en række forestillinger og myter fra det 19. århundrede, der identificerede den tyske kunst med et nyt Tysklands komme, hvor alle tyskere ville være kunstnere og ville være ledet af en kunstnerfører. Sådanne idéer kom tydeligst til udtryk i Julius Langbehns meget populære bog Rembrandt als Erzieher, hvor Langbehn gjorde Rembrandt til den moderne verdens antitese og til det kom- 
mende Tysklands profet. Et kommende Tyskland, der skulle basere sin eksistens på kunst, genialitet og magt og efter en destruktion af det moderne samfund skulle skabe rum for menneskets elementære passioner. At gøre kunst til et løfte om tysk lykke var, hvad det nazistiske regime gjorde og det var derfor, at Hitler præsenterede sig som kunstner, hvis erfaringer ud i det kreative udgjorde den bedste garanti for hans kapacitet til at gøre Der Volksgeist til middel for skabelsen af det perfekte rige.

Når den traditionelle historiske og kunsthistoriske reception af det nazistiske regimes storstilede brug af kunst mener at kunne forklare dette forhold med henvisning til nazismens propagandamaskineri, overser de den autoaffirmative proces, som kunst udgjorde for nazismen. ${ }^{56}$ Nazismen underkuede ikke kunsten med politiske hensigter, tværtimod tilskrev den kunsten en frelsende kraft og Hitler insisterede på »det synliges og sanseliges effekt» for at sikre folket »dets fornyede autobekræftelse«. ${ }^{57}$

Den inversion, som vi konstaterede, var på spil i nazismens forestillinger om, at Hitler var det nazistiske parti, som var Tyskland, som var Hitler, og fungerede på baggrund af en gensidig inkorporation og identifikation af Hitlers krop med den politiske krop, med corpus mysticum. Som Lefort og Kantorowicz hjalp os til at se, var der tale om en variant af den kristne model, hvor Kristus identificeredes med kirken, der i nazismen førtes til sin yderste konsekvens - den frelsende kraft og vilje kan kun komme fra folket selv, men kun hvis det er muligt for ét element at genskabe folkets tro på sig selv. ${ }^{58}$ Dette ene element var kunstneren Hitler, der skulle emancipere politikken fra dens bureaukratiske fængsel af normer, hensyn og regler. Idet kunst var viljens praktiske udtryk, evnen til at omdanne kaos til stabile former, kunne nazismen ved at fremmane Hitlers kunstneriske evner forlene sin leder med en karismatisk og syntetisk kraft, der opfyldte massernes forventninger. ${ }^{59}$ Som den karismatiske kunstner han var, suspenderede Hitler alle institutionaliserede normer og juridiske forudsætninger, og kun han kunne genskabe folkets tro på sig selv.

\section{Myte som virkelighed}

Projektionen af æstetisk genialitet over på den politiske sfære forkastede Weimar-republikkens generelle beslutningsprocesser til fordel for massens overgivelse til lederens karisma. Nazismens mål var at skabe »et karismatisk fællesskab ${ }^{60}{ }^{6}$ Hitler understregede også selv gang på gang i Min Kamp, at det vigtige ved massemøderne ikke var talernes indhold, men den synlige succes eller autosuggestionen, der skulle skabe vilje og selvsikkerhed i massen. ${ }^{61}$ 
»Publikum informeres ikke, det optræder og dets optræden 'skaber historie" «. ${ }^{62}$ Det vigtige ved massemøderne var at skabe en stemning, der kunne overbevise det isolerede individ om nazismens kraft og der igennem om egen kraft. Det vigtige, når man stod mellem 200.000 mennesker, der kæmpede for den samme idé, var ikke at forstå det, der blev sagt, men at man troede på det. $^{63}$ Troen var det primære. The medium was the message. Som Klaus Theweleit skriver: »Fraværet af en egentlig substans garanterede ritualets succes. 'Sammenføring', ‘berøring', 'avl', ‘illumination’ kunne kun ske, fordi koncentrationen ikke var rettet mod det sagte: de forsamlede var ikke samlede for at tænke eller for at lære ${ }^{64}$ Den synlige demonstration af vilje og kraft blev forstærket ved, at suggestionen af den inkorporerede masse konvergerede med forøgelsen af kraften, der således forhøjede tilliden og troen på den kommende magts synlighed. Autoproduktionen udløste en quasi-refleksiv automatik, der mest af alt mindede om autoerotik i sin perfekte cirkelslutning mellem årsag og effekt.

Som Joachim Fest gør opmærksom på, var der en tydelig erotisk og seksuel stemning over de nazistiske massemøder, der havde karakter af en kollektiv forening af den mandlige kunstner og den feminine masse. En ekstatisk stemning var resultatet af suggestionen og autosuggestionen. »Tonefilmsoptagelser fra den tid gengiver tydeligt mødernes ejendommeligt obskøne, seksuelle karakter: først åndeløs stilhed, så enkelte, korte skrig, stigningerne, de første lyde af befrielse fra mængden, svimlende rus, nye stigninger og til slut ekstasen, hvor taleorgasmen strømmer frit og uhæmmet«. ${ }^{65}$ Den lille mand med den hårdtspændte og forvredne krop, der badet $\mathrm{i}$ lyset fra projektørerne mest af alt mindede om et menneskeligt projektil, slyngede og skreg staccatoagtigt ord ud over den feminine masse og krop og trådte derved i karakter som det Tredje Riges (pik)hoved.

Disse massemøder var den narcissistiske oplevelse som både føreren og folket ventede på: erfaringen af det autentiske, af hic et nunc, oplevelsen af das Volksgeist' forening med der Volkskörper. Det var simpelthen oplevelsen af folkets grundlæggelse som subjekt, en grundlæggelse, der ekskluderede alt fremmed og aktiverede sine relationers symbolik. »Endelig er myte og virkelighed ét: set som et hele, er talen en perlokutionær handling. Den kræver en stor national samhørighed for nuet (et tættere Volksgemeinschaft) som Tyskland har kendt gennem alle dens histories århundreder, og gennem selve affirmationsakten realiseres kravet. ${ }^{66}$

Det er derfor, at de store ceremonier, vi kender som selve symbolet på Nazityskland, ikke blot var simple midler for at nå et ydre mål: de fandt deres mål i selve oplevelsen, i das Erlebnis af fællesskabet, der lukkede sig om sig selv. Hitler skabte Tyskland og Tyskland skabte Hitler, og den gensidige ska- 
belse af massen og dens fører præsenterede sig som autoproduktionen af én eneste politisk-religiøs krop. Som Fest citerede juristen Ernst Rudolf Huber for: »Det nye og afgørende ved førerforfatningen er, at den overvinder den demokratiske skelnen mellem regerende og regerede; den sætter i stedet en enhed, hvori fører og følgeskab er smeltet sammen. ${ }^{67}$ Disse narcissistiske manifestationer fungerede på baggrund af en simpel og konsekvent eksklusion af alt, havde der kunne udgøre en forhindring for konstruktionen af fører-flok-monaden. ${ }^{68}$ Politik var et spørgsmål om intensitet og ikke substans, som den tyske jurist Carl Schmitt skrev. Ifølge ham var de liberal-kapitalistiske samfund prægede af en fortsat neutralisering af livet, en proces som nåede sin kulmination i det øjeblik, hvor de pluralistiske og afpolitiserede former indgik i det politiske liv som rent tekniske foranstaltninger. Han protesterede mod de tilsyneladende fredsslutninger og pointerede, at når de antagonistiske forhold stadig eksisterede, medførte fredsslutningerne et tilbagetog fra virkeligheden. Dermed fjernede man de berøringsflader, som politik opstår af - man begravede det politiske. Når politik først og fremmest var et spørgsmål om intensitet var det undtagelsen og ikke normen, der var det vigtige. Det var undtagelsen - førerens suveræne beslutning - og diskontinuitetens temporale semantik, der ødelagde normen, og ud af normens ruin kunne det politiske livs ontologisk højere mulighed vokse. »Det normale beviser intet, undtagelsen beviser alt [...] I undtagelsen bryder det virkelige livs kraft gennem skorpen på en i gentagelse størknet mekanik «. ${ }^{69}$

Hitlers tilsynekomst på massemøderne var ensbetydende med bortgangen af enhver fjende af Das Volksgemeinschaft. Hitler inkarnerede løsningen på alle konflikter, derfor var det alfa og omega, at massen i massemødets Erlebnis forstod anticipationen som selve konfliktens løsning. Inklusions- og eksklusionsmekanismen, der var nødvendig for, at den autentiske erfaring kunne indfinde sig, blev sat i scene gennem massens svaren 'ja' eller 'nej' til Hitlers spørgsmål, der konstruerede en simpel opposition mellem et indre ideal-fællesskab, og et ydre, der var fjender, der ikke troede på fællesskabets kærlighed og derfor måtte gøres synlige og ekskluderes. Gennem et »abortsprog« gav den mandlige kunstner Hitler fødsel til et velformet Tyskland. ${ }^{70}$ Ved at transfigurere politisk handling gennem billedet af æstetisk produktion appellerer Hitler til massens karismatiske håb og begær efter forandringer og fællesskab. Massen var både objekt og aktør i det nazistiske skuespil, var både beskuere og materiale for Hitlers kunstneriske handlinger, der vækkede massens følelser og benægtede dem. Hitler selv inkarnerede løsningen på alle konflikter, og de forventninger han skabte, og som det nazistiske regime forsøgte at skabe om Hitlers kunstneriske evner, var løsningen på alle konflikter og problemer. Det var derfor, at fotografier af Hitler som taler blev masse- 
producerede og distribueret over hele Tyskland. ${ }^{71}$ Fotografierne skulle skabe forventning hos massen og hos Hitler. Det nazistiske regime forsøgte at skabe en fælles forventning, et fælles billede, som massemøderne og ceremonierne skulle give krop til. Derfor afhang massemødernes succes ikke så meget af deltagernes 'oprigtighed', som af deres tro på det skabte billede.

\section{Virkelighed og repræsentation}

Den meget udbredte tendens i historiske og kunsthistoriske kredse til at læse nazismens brug af kunst som udtryk for propaganda hænger uløseligt sammen med tendensen til at operere med en problematisk virkelighedsopfattelse. ${ }^{72}$ Når den engelske historiker Ian Kershaw skriver: »hvor nazismen var ambitiøs - og endda ekstraordinært ambitiøs - var i forsøget på at forvandle den subjektive bevidsthed og ikke den objektive virkelighed «, ${ }^{73}$ så er det udtryk for en form for naivitet. Er en transformation af den subjektive bevidsthed mulig uden samtidig at medføre en transformation af de objektive realiteter? Lod nazismen den objektive realitet intakt? Under en sådan formulering aner man en idealistisk forestilling om en pseudobestemt virkelighed, der er mere virkelig end den virkelighed, som nazismen var med til at skabe. Ifølge Kershaw reducerede nazismen det reelle til en repræsentation, der reelt ikke ændrede noget ved de økonomiske og psykosociale forhold i det kapitalistiske samfund, men blot intensiverede den erfaringsdestruktion og homogenisering, som bl.a. kendetegner den kapitalistiske civilisation. Nazismen løste kun samfundets 'virkelige' problemer på et 'illusorisk' niveau. Kershaw analyserer altså det nazistiske regime og dets mytologi på baggrund af en distinktion mellem det reelle og repræsentationen, der bruges til at indføre en simpel ideologimodel, hvor 'virkelige' modsætninger løses på et 'uvirkeligt' niveau. Men er vi i stand til at forstå det nazistiske regime og dets brug af kunst, hvis vi kun prøver dens virkelighedsproduktion mod en social facitliste, som om en sådan var den absolutte visdoms ubetvivlelige visdomsord, og som om en sådan netop ikke også hele tiden skal prøves mod den virkelighed, der hele tiden skabes. At overholde samfundsanalysens dogmer blindt medfører altid, at vi tildeler tanken forrangen og underordner det materielle under begreberne. Det nazistiske regime og dets kunstnerfører var med til at skabe en virkelighed, som vi må prøve at skabe kategorier til, ikke applikere allerede rejste begreber på. ${ }^{74}$ Nazismens tilhængere flygtede ikke fra virkeligheden over i en repræsentation, snarere var der tale om, at de i utilfredshed med virkeligheden ændrede den, som Georges Bataille gjorde opmærksom på allerede i 1934. Den socioøkonomisk definerede virkelighed blev marginali- 
seret af dens marginaliserede subjekter og således problematiserede nazismen ideologiens og økonomiens hegemoniske homologi til fordel for æstetikkens evne til determination. ${ }^{75}$

I forlængelse af forestillingen om den objektive virkeligheds uændrede form er en række historikere begyndt at fremskrive forestillingen om 'det dobbelte liv under nazismen', hvor tyskerne på den ene side var flinke apolitiske individer og på den anden side var opslugte i den nazistiske krigsmaskine. "Det lykkedes nationalsocialismen at rejse en 'anden verden' med et netværk af organisationer under den i største udstrækning stabilt elskede traditionelle sociale orden, i hvilken de traditionelle kriterier for social indflydelse og placering ikke havde nogen betydning «. ${ }^{76}$ Ifølge disse historikere skete der en fordobling i det Tredje Rige; tyskernes verden udgjordes på skift af to forskellige og adskilte virkeligheder. I den ene virkelighed ignoreredes nazismen og dens massemøder, uniformer og drab. Det nazistiske regime gennemsyrede ikke den almindelige hverdag for den almindelige tysker, skriver den tyske historiker Christian von Krockow. »Hvad talerne besvor og billederne viste, var kun den halve sandhed. Hverdagen i det Tredje Rige så anderledes, mere dagligdags og normal ud. Værnemagten opdragede militært, ikke nationalsocialistisk; masseorganisationen SA levede efter 1934 en skyggetilværelse, og dens 'kammeratskabs'-aftener fik først og fremmest ølforbruget til at stige; Hitlerjugend, det var noget, man - i den udstrækning tjenesten fandt sted - var to, tre timer onsdag og lørdag eftermiddag. Det meste af tiden levede langt de fleste tyskere en civil tilværelse, sådan som de altid havde gjort det. "77 $^{77}$ Problemet med von Krockows teori om 'dobbeltmenneskene' er, at han tenderer til at overse eller underspille den vigtige rolle, som hverdagslivet spillede for det nazistiske regime og derved praktiserer hvad Eric Santner har kaldt 'narrativ fetichisme'. Ved narrativ fetichisme forstår jeg konstruktionen af en fortælling, som bevidst eller ubevidst er skabt med det formål at slette sporene efter det traume eller tab, som oprindeligt fremkaldte fortællingen [...] [D]et er måden, hvorpå en manglende evne eller afvisning benytter traumatiske begivenheder; det er en strategi, hvormed noget ophæves i fantasien, hvormed behovet for at sørge ophæves ved at simulere en tilstand af intakthed, typisk ved at placere tabets oprindelse andetsteds ${ }^{78}{ }^{78}$

Von Krockow finder bl.a. sin teori om den dobbelte virkelighed bekræftet i det faktum, at en stor mængde af de spillefilm, som blev produceret i det Tredje Rige tilsyneladende intet havde med nazismen at gøre. Der var ingen uniformer, ingen hagekors og ingen partiemblemer i tidens populære film. Problemet med von Krockows teori er blot, at de umiddelbart apolitiske film netop qua apolitiske spillede en central rolle i den nazistiske mytekonstruktion og dets æstetiserede visioner. Filmene var en integreret del af myten om 
det tyske folks autoproduktion og udgjorde en kalkuleret 'frizone', hvor fællesskabet kunne opretholdes før næste massemøde. Som Eric Rentschler skriver var »de nazistiske films politiske effekt [...] ikke kun propagandaens simple funktion overført af dialog [...] Hvad er mere vigtigt er den polyfoniske måde, på hvilken nazistiske film kanaliserer perception og gengiver virkeligheden, hvordan billeder og lyde fungerer på et utal af måder for at udtrykke hele den menneskelige eksistens, og præsenterer et verdenssyn, som bogstaveligt talt forsøger at gengive - og kontrollere - alt. « ${ }^{79}$ Det er en misforståelse, hvis man som von Krockow tolker ‘tolerancen' som andet end en nødvendig del af myten om det tyske folk, for tolerancen forøgede folkets velvære uden at den hæmmede konstruktionen af myten og realiseringen af den tyske idé. "Af stor betydning var brugen af let underholdning i et forsøg på at binde det tyske Volksgemeinschaft sammen [...] i en stor lykkelig familie ${ }^{80}$ Det nazistiske diktatur havde brug for adspredelse og underholdning, og alt, hvad der ikke obstruerede for myten, blev tilladt, for på den måde at kæde myte og virkelighed sammen. ${ }^{81}$ Som Rentschler gør opmærksom på, havde det nazistiske regime slet ikke til intention at skabe en éndimensionel kultur og f.eks. kun lave stærkt 'politiske' film. »Nazistisk filmkultur - og nazipropaganda generelt - skal forstås under henvisning til, hvad Goebbels kaldte 'orkesterprincippet'.»Vi forventer ikke at alle spiller det samme instrument», sagde han [Goebbels] ; "vi forventer blot at alle spiller den samme melodi« [...] NaziTysklands film, dokumenterede og ugerevyer gennemtrængte, sammen med en imponerende række af orkestrerede diversioner, [...] hverdagen med en aura af drama og spænding, organiserede arbejdet og fritiden, fyldte fysisk og psykisk rum og kæmpede således mod alternative erfaringer og uafhængige tanker «. ${ }^{82}$

For nazismen var det hul, der muligvis eksisterede mellem tyskernes deltagelse i den nazistiske realitet og deres overbevisning af sekundær betydning. Det primære var den effektivitet, som tyskeren gav prøver på i sin handling, sin præstation. Det nazistiske regime var overbevist om, at massemødernes suggestive stemninger og ceremoniernes repetitive handlinger nok skulle skabe en favorabel stemning i den enkelte tysker. De dikterede en bestemt adfærd og var sikre på, at den indre stemning nok skulle ende med at indfinde sig. Det vigtige var således ortopraksi ikke ortodoksi. Dette kom også til udtryk i den lange række af ritualer, som nazismen approprierede fra kristendommen: dåben blev til navneceremonien, førerens billede erstattede korset bag altret, og når folk blev gift fik de et eksemplar af den nye tyske bibel Min Kamp.

Ud over at von Krockows forestilling om en dobbelt virkelighed negligerer den nazistiske mytes orkestrering, så afslører den tillige en ukritisk og upro- 
blematisk ideologiopfattelse. Den omvending - ideologi er både et resultat af en fundamental adskillelse mellem ånd og materie $o g$ af en uundgåelig afvisning af denne adskillelse $\mathrm{i}$ åndens navn - som ideologien iværksætter og udgør, leves som var den sand. Der er således ikke tale om, at den nazistiske mytologi var en illusion, der skal afsløres; det ideologiske fænomen er ikke en fejltagelse, men en effekt af historiske livsprocesser. Von Krockows forestilling om to adskilte virkeligheder hviler på en forestilling om, at den falske nazistiske ideologi skjulte en anden 'ikke-ideologisk' virkelighed, der var fri for de nazistiske forbrydelser. Men som Stephen Heath skriver: "når individet står foran ideologiens skærm [...] ser han eller hun et virkeligt billede, sandt, rettet ind, og med han/hende i position med det, også medieret, præsenteret og repræsenteret. Det er ikke muligt at vende sig om mod (eller tilbage til) virkeligheden som til en direkte lyskilde, det er ikke muligt at putte øjet til hullet for at se verden udenfor. Ideologi dukker frem fra de historiske livspraksisser, kampen er i virkeligheden, som inkluderer ideologi som en reel del af dens tilstedeværelse, historisk, socialt og subjektivt «. ${ }^{83}$ Den ideologiske afbrydelse er aktiv i virkeligheden selv, og derfor må vi afvise von Krockows beskrivelse af nazismen.

\section{Noter}

1. „Kunst als Fundament für der kreative Wille im Politik« in: Völkischer Beobachter, den 24. april, 1936; her citeret fra: Lionel Richard: Le Nazisme et la Culture, Bruxelles 1988, p.188. Med mindre andet angives er alle oversættelser til dansk mine egne.

2. Jvf. Joachim Fest: Hitler. En Biografi, København 1974, bind 1, pp.32-67. Oversættelse ved Per Gosler.

3. Op.cit., p.61.

4. Adolf Hitler: Hitlers Tischgespräche im Führerhauptquartier 1941-42. p.323. Her citeret fra: Fest: Hitler, bind 2, p.133.

5. „Kunst als Fundament für der kreative Wille im Politik«; citeret fra: Richard: Le Nazisme et la Culture, p.188.

6. Adolf Hitler Min Kamp 1/2, København 1994, pp.24-54. Oversættelse ved Clara Hammerich.

7. Jvf. Jonathan Petropoulos: Art as Politics in the Third Reich, Chapel Hill 1996, p.267; p.375.

8. Philippe Lacoue-Labarthe og Jean-Luc Nancy skriver i deres fremragende tekst Le Mythe Nazi (La Tour d'Aigues 1996), at nazismen var "produktionen af politik som kunstværk«, loc. cit., p.49. Min analyse af nazismens brug af kunst trækker metodisk på Lacoue-Labarthe og Nancys analyse i forsøget på mindre at afmytologisere nazismens kunst og mere at undersøge kunstens rolle i den nazistiske mytologi. "[V]i forsøger at undgå at devalorisere de nazistiske myter, forstået på den måde, hvormed en kritisk, ekstremt forfinet analyse (nemlig Roland Barthes') har 
kunnet $[\ldots]$ afmontere de mytologier, som for kort tid siden strukturerede det franske småborgerskabs sociokulturelt ubevidste. Foran et fænomen med et sådant omfang og en sådan massivitet som nazismen har en sådan analyse ingen interesse - og selv ingen relevans«, loc.cit., p.20. Ifølge Lacoue-Labarthe og Nancy er det vigtige ved nazismen og dens myte ikke så meget dens konkrete indhold, som det er dens struktur og mytens performative funktion. Nazismens specificitet ligger ikke i dens ideologiske materiale, men i troen på mytens narrative effektivitet i konstruktionen af national identitet.

9. En ideologi er altid usikker, ifølge Louis Althusser (Sur la Reproduction, Paris 1995). Ideologi refererer således ikke til rationelt konciperede ideer, men i stedet til den imaginære måde, på hvilken folk lever deres relation til deres eksistens’ egentlige betingelser. Ideologi praktiseres og er ikke rationelt udtænkt, men er ubevidst, modsætningsfuld og fantasmatisk. Analysen skal derfor ikke abstrahere elementer, men forsøge at finde »den ideologiske diskurs» distinktive enhed «. Diskursens ideologiske specificitet findes ikke i én enkelt idé, som cirkulerer i den, men findes i elementernes relationer. I forholdet mellem politik og kunst, lyder spørgsmålet således: hvordan forbindes kunst og politik i nazismen? En sådan tilgang synes mere produktiv konfronteret med nazismens hybride og intertekstuelle verden.

10. Jvf. Jean-Pierre Faye: Théorie du Récit. Introduction aux 'Languages Totalitaires'. Critique de la raison, l'economie narrative, Paris 1972, p.9; pp.102-3. Faye giver en inspirerende redegørelse for, hvorledes historien producerer sig selv gennem narration. David Kertzer viser i sin Rituals, Politics, and Power (New Haven 1988), hvorledes "ritualer altid har været og altid vil være en essentiel del af det politiske liv, brugt til at symbolisere, simplificere og understrege politiske budskaber", op.cit., p.2.

11. Som følge af æstetikkens flertydighed har jeg udvidet min analyse til at omfatte troper, som ikke nødvendigvis er æstetiske. Troperne omfatter f.eks. grundlæggelse, kraft og modtagelighed, materiale og forbrug. Jeg har i analysen valgt at fokusere på Hitlers konstruktion af KunstnerFøreren i forhold til nazismen og i forhold til massen.

12. Susan Buck-Morss: „Æstetik og anæstetik. Walter Benjamins 'kunstværkessay' revurderet« in: Kultur \& Klasse 77 (1994). Oversættelse ved Bert van Heel. Se også: Terry Eagleton: The Ideology of the Aesthetic, London 1990.

13. Jvf. Peter Bürger: Theorie der Avantgarde, Frankfurt 1974, pp. 25-29; p.67.

14. Susan Buck-Morss skriver: »Estetikken tillader en anæstetisering af receptionen, en betragtning af 'scenen' med en desinteresseret nydelse, selv om den samme scene rituelt er et helt samfunds forberedelse til betingelsesløs ofring og i sidste ende tilintetgørelse, mord og død«, loc.cit., p.79.

15. Louis Marin har i Le portrait du roi (Paris 1983) og i Pouvoirs de l'image (Paris 1993) vist, hvorledes repræsentation er magtens essens, idet magten ikke har nogen eksistens udenfor dens repræsentation. Derfor eksisterer magten ikke, den udøves. Der trækkes tunge veksler på Marins analyser i det følgende.

16. Se Leo Bersanis The Culture of Redemption, Cambridge 1990, for en overbevisende analyse af forestillingen om, at kunst kan redde mennesket fra historiens katastrofer. Bersani kritiserer med nedslag i en række centrale forfattere og filosoffer den vidt udbredte idé, at kunst er en slags helbredende fuldendelse af livet. Ifølge Bersani er en sådan idé kun mulig på baggrund af en devaluering af livet og kunsten. Han afviser forestillingen om, at »kunstværket har autoritet til at mestre 
erfaringens tilsyneladende råmateriale på en sådan måde, at det får værdi og måske endda frelses«. Man forveksler i så fald kunst med filosofi og mener, at »kunst ideelt ville være sandhed befriet fra fænomen", op.cit., p.1-2.

17. Otto Karl Werckmeister har analyseret tegningen i sin tekst »Hitler the Artist« (in Critical Inquiry, nr. 23 (1997)) som led i en redegørelse for det produktive aspekt af Hitlers engagement i kunst. Jeg knytter an til Werckmeisters, der undersøger betydningen af nazismens overførsel af kunstnerisk kreativitet til politisk aktivitet.

18. Joseph Goebbels i brev dateret den 11. april 1933 til Wilhelm Furtwängler, her citeret fra: Hildegaard Brenner: Die Kunstpolitik des Nationalsozialismus, Hamburg 1963, p.178.

19. Jean-Joseph Goux: „Politics and Modern Art. Heidegger's Dilemma«in: Diacritics, vol. 19, nr. 3/4, 1989, p.17.

20. Jeg har hentet forestillingen om virkeligheden som et nervesystem fra Michael Taussig: The Nervous System, London 1992, pp.1-10.

21. Hitler i Fest: Hitler, bind 2, p.132.

22. Adolf Hitler: Die Deutsche Kunst als stolzeste Verteididung des deutschen Volkes (München 1934) citeret fra Brenner, op.cit., p.124.

23. Se Gilles Deleuze og Félix Guattari for en differentiering mellem den 'molekylære' masse og den 'molære' masse, som den udfoldes i L'Anti-Oedipe. Capitalisme et Schizophrénie (Paris 1972), hvor de gør rede for, hvordan det kollektive og subjektive indgår i forskellige og modstridende relationer. Den molekylære masse er kendetegnet ved mangfoldighed og forvandling, mens den molære masse er kendetegnet ved enhed og udgøres af afgrænsede blokke organiseret om et centrum. Som Klaus Theweleit har vist, er den nazistisk kontrollerede masse forsøget på helt at tæmme den molekylære masse med dominansens molære arrangement. Jvf. Männerphantasien (Frankfurt a.M. 1978).

24. Hitler i: Fest: Hitler, bind 2, p.136.

25. Jvf. Susanna Barrows: Distorting Mirrors: Visions of the Crowd in Late Nineteenth-Century France, New Haven 1981, og Robert Nye: The Origins of Crowd Psychology: Gustave Le Bon and the Crisis of Mass Democracy in the Third Republic, London 1975.

26. Hitler kaldte sig sigende »Europas største skuespiller«. Jvf. Fest: Hitler, bind 2, p.124.

27. Fest: Hitler, bind 2, p.60.

28. Hitler: Min Kamp, bind 1, p.130.

29. Hitlers drøm om mandlig partenogenese er en variant af en bestemt idealistisk filosofisk tradition, som ifølge Jean-Joseph Goux er kendetegnet ved »en forestilling om forestilling «. Forestillingen om hvorledes kvinden udgør materialet som manden skal give form. En forestilling, hvis afkom er den filosofiske modstilling mellem materie og ånd. I denne tradition stræbes der efter en sexløs forplantning, hvor faderen takket være begær og form føder sønnen uden behov for 'moderens' mediering. Jean-Joseph Goux: Économie et symbolique, Paris 1973, pp.239-256.

30. Hitler: Min Kamp, bind 1, p.40.

31. Hitler: Min Kamp, bind 1, p.143.

32. Susan Buck-Morss: „Estetik og anæstetik. Walter Benjamins 'kunstværkessay' revurderet«, p.53.

33. Ifølge Saul Friedländer var nazismens Weltanschaung baseret på en fascination af død og destruktion. Friedländer argumenterer for, at Nazismen degraderede og trivialiserede døden, forvandlede den til et billede og derved fortrængte dens men- 
neskelige og eksistentielle aspekter. Jvf. Reflets du Nazisme, Paris 1982.

34. Adolf Hitler i Mitteilungsblatt der Reichkammer der bildenden Künste, nr. 2, 1938; her citeret fra Klaus Backes: Hitler und die Bildende Künste, Köln 1988, p.54.

35. Hitler citeret fra: Fest: Hitler, bind 2, p.119

36. Hitler citeret fra: Fest: Hitler, bind 2, p.40.

37. Hitler citeret fra: Fest: Hitler, bind 2, p.122.

38. Ian Kershaw: The Hitler Myth: Image and Reality in the Third Reich, Oxford 1987, p.1.

39. Joachim Fest skriver: „Det er [...] ikke uden betydning, at der blandt de nationalsocialistiske ledere fandtes et uforholdsmæssigt stort antal halvkunstnere: foruden Hitler selv var der Dieter Eckhart, Goebbels, der ikke havde succes som romanforfatter, Rosenberg, der var begyndt som arkitekt, von Schirach og Hans Frank som digtere, Funk, der havde forsøgt sig som musiker«, Hitler, bind 1, p.337.

40. Jvf. Peter Reichel: Der Schöne Schein des Dritten Reiches. Faszination und Gewalt des Faschismus, München 1991. Reichel skriver bl.a.: »Personificeringen af politik synes at overvinde de strukturelle og anonyme aspekter af det moderne samfunds politik, dvs. ret, reglementeret adfærd, bureaukrati, osv. I hvert fald lover den autenticitet, emotionalitet og symbolsk repræsentation og således kompensation for den undertrykkende og desorienterende fremmedgørelse i industriog massesamfundet«, op.cit., p.155.

41. Russell Berman: "Written Right Across Their Faces«, in: David Bathrick (ed.): Modernity and the Text, New York 1989, p.61.

42. Daniel Guérin: La peste brune, Paris 1978, pp.68-9.

43. Claude Lefort: Les formes de l'histoire. Essai d'anthropologie politique, Paris 1978 og L'invention démocratique. Les limites de la domination totalitaire, Paris 1981.

44. Ernest Kantorowicz: The King's Two Bodies. A Study in Medieval Political Theology, Princeton 1957.

45. Claude Lefort: Essais sur le Politique XIX - XX Siècles, Paris 1986, p.27.

46. Claude Lefort: L'invention démocratique, p.99.

47. Op.cit., p.101.

48. Op.cit., p.101-2.

49. Hitler i Fest: Hitler, bind 1, p.288.

50. Jean-Joseph Goux: „Freud et la Structure Religieus de Nazisme» in: Les Iconoclastes, Paris 1978, pp.56-7.

51. Hitler fra Fest: Hitler, bind 1, p.225.

52. Julius Langbehn: Rembrandt als Erzieher. Von einem Deutschen, Leipzig 1890, p.10. Se Fritz Stern: The Politics of Cultural Despair. A study in the Rise of the Germanic Ideology, Berkeley 1961, for en analyse af Langbehns bog.

53. Fest: Hitler, bind 2, p.60.

54. I forlængelse af Daniel Dayan bruger jeg termen 'suture' i betydningen det moment, hvor subjektet 'overtales' til at acceptere bestemte 'billeder' som en præcis refleksion af vedkommendes situation. Denne tvang sker 'transparent', dvs. 'enonciationsapparatet' skjules. Jvf: „The tutor code of classical cinema« in: Bill Nichols (ed.): Movies and Methods, Berkeley 1976.

55. Russell Berman »Written Right Across Their Faces«, p.61.

56. Som Lacoue-Labarthe og Nancy skriver: »Nazi myten [...] er konstruktionen, skabelsen og produktionen af folket i, gennem og som et kunstværk«, Le Mythe Nazi, p.49. Lacoue-Labarthe og Nancy redegør for den nazistiske mytes autoproduktive 
struktur, men bestemmer denne som specifik tysk. Denne bestemmelse er muligvis problematisk, idet nazismen selv gjorde krav på det særligt tyske for at give krop til fantasmet om den radikale autonomi. Roger Griffin har redegjort for, hvorledes nazismen er en del af fascismen, dvs. et ikke-tysk fænomen, der bestemmes som en sammenhængende og relativt original ideologi, ikke når det drejer sig om dens doktriner, men om dens primære myte, nemlig genfødsel eller palingenese. Jvf. The Nature of Fascism, London 1991, pp.110-2.

57. Adolf Hitler: Die Reden Hitlers am Reichparteitag 1933, München 1934, p.12.

58. Slavoj Zizek redegør i The Sublime Object of Ideology, London 1989, for, hvorledes nazismen refeticherer Hitler ved at fetichere folket $i$ lederen. Hitler får værdi, ikke fordi han er en form for superhelt, men fordi han repræsenterer det tyske folk. I ham kommer folkets 'karisma' til udtryk. Det er først og fremmest folket som valoriseres i nazismen, derved viser nazismen sig som en variant af den moderne historie om, hvorledes det urolige politiske subjekt 'hoben' gennem nationen oversættes til 'folket'. Hoben er modernitetens kætterske subjekt, som truer den etablerede orden. Folket derimod er et element i en cirkulær forestilling om magt, ved hjælp af hvilken magten forvandler hoben til ét subjekt, folket, der siden legitimerer denne magt. Jvf. Paolo Virno: Mondanità. L'idea di 'Mondo' tra esperienza sensibile e sfera pubblica, Roma 1994.

59. Max Weber karakteriserede en autoritet, der hviler op af lederens ekstraordinære kvaliteter, som karismatisk. Den karismatiske leder afbryder historiens kontinuum takket være sine overmenneskelige evner. "Karisma' benævner en hinsides hverdagen [...] gældende kvalitet, som beskriver [...] 'Førerens' overnaturlighed og overmenneskelighed«. Wirtschaft und Gesellschaft. Grundriss der verstehenden Soziologie, Tübingen 1976, p.140.

60. Roger Griffin: »Staging the Nation’s Rebirth« in: Günter Berghaus (ed.): Fascism and Theater, Oxford 1996, p.16.

61. Hitler: Min Kamp, pp.125-31.

62. J. P. Stern: Hitler - The Führer and the People, Glasgow 1975, p.37.

63. Jeg karakteriserer ikke de nazistiske massemøder og ritualer som 'indholdsløse' og udtryk for ren overflade, når jeg skriver, at det vigtigste ved massemøderne var 'oplevelsen' og ikke talens indhold. Som Mary Douglas har vist, er ritualer historien udtrykt i symbolsk form og ikke tomme gestus. Jvf. Naturlige Symboler, Viborg 1975, pp.24-7. Oversættelse ved Kirsten P. Hansen

64. Theweleit: Männerphantasien, bind 2, p.150.

65. Fest: Hitler, bind 1, p.288.

66. J. P. Stern: Hitler - The Führer and the People, pp.35-42.

67. Ernst Rudolf Huber: Verfasungsrecht des Grossdeutschen Reiches; her citeret fra: Fest: Hitler, bind 2, p.60-1.

68. Stern: Hitler - The Führer and the People, p.37.

69. Carl Schmitt: Politische Theologie. Vier Kapitel zur Lehre der Souveränität, Berlin 1996, p.22.

70. Faye: Théorie du Recit, p.81-2.

71. Det er den tyske fotografi- og kunsthistoriker Rudolf Herz, der i sit studie af Heinrich Hoffmanns funktion i skabelsen af forestillingen om kunstnerføreren 'afslørede', at fotografierne var beregnet til massedistribution og ikke blot var private øvelsesfotografier. Jvf. Hoffmann \& Hitler. Fotografie als Medium des FührerMythos, München 1994, pp.106-17.

72. Jeg tillader mig at henvise til min artikel »Kunst, Historie og Nazisme. Bemærk- 
ninger om receptionen af nazismens forhold til kunst og ansats til en revurdering", in: Periskop, nr. 12 (under udgivelse).

73. Ian Kershaw: The Nazi Dictatorship. Problems and Perspectives of Interpretation, London 1985, p.142.

74. Som Theodor W. Adorno skriver i Den Ny Musiks Filosofi: „Den dialektiske metode, og netop den som står på benene og ikke på hovedet, kan ikke afhandle de enkelte fænomener som illustrationer eller eksempler på noget allerede faststående, og som noget der er undtaget fra begrebets egen bevægelse; i så fald udarter dialektikken sig til statsreligion. Tværtimod fordres det, at det almene begrebs kraft overføres på den enkelte genstands selvudvikling og at dennes samfundsmæssige gådebillede opløses ved hjælp af kræfterne fra dens egen individuation«. Den Ny Musiks Filosofi, København 1983, p.30.

'Generelt' kan vi sige, at der i enhver reference til 'den objektive virkelighed' ligger en forestilling om, at der findes en sidste instans, 'en virkelig virkelighed'. I en sådan forestilling opererer en idealisme, der forsoner begreb og materialitet i og for tanken. Jvf. Jacques Derrida »La Mythologie Blanche«, in: Marges de la Philisophie, Paris 1972.

75. Jvf. Georges Bataille: »La structure psychologique du fascisme« (in: Oeuvres Complètes, Paris 1970, bind I), hvor Bataille gør opmærksom på, hvorledes traditionelle hegemoniformer problematiseres af nazismen, idet dens ideologiske dominans ikke er et resultat af økonomisk magt. Bataille kritiserer marxismen for ikke at være i stand til at analysere nazismen, fordi den forbliver fanget i forsøget på at føre enhver overbygning tilbage til basis.

76. Jens Alber: »Nationalsozialismus und Modernisierung«in: Kölner Zeitschrift für Soziologie und Sozialpsychologie, nr. 41, 1989, p.348.

77. Christian von Krockow: Tyskland 1890 - 1990, København 1996, p.169. Oversættelse ved Hans Fink.

78. Eric Santner: »History beyond the Pleasure Principle« in: Saul Friedlander (ed.): Probing the Limits of Representation. Nazism and the 'Final Solution', Cambridge 1992, p. 144.

79. Eric Rentschler: The Ministry of Illusion: Nazi Cinema and its Afterlife, Cambridge 1996, p. 169.

80. David Bathrick: »Making a National Family with the Radio: The Nazi Wunschkonzert« in: Modernism/Modernity, vol. 4, nr. 1, 1997, p.116.

81. Selvmobilisering var et meget udbredt fænomen i det Tredje Rige: hvert år før krigen deltog en million frivillige i det årlige Winterhilfe (velgørenhedsarbejde organiseret af Kraft durch Freude), adskillige millioner unge blev rekrutteret til Hitlerjugend, mere end to millioner tyske arbejdere lod sig indskrive som lærlinge i den nazistiske fagforening, otte millioner tyskere var med i lokale militærkorps, og mere end 54 millioner havde deltaget i en eller anden form for Kraft durch Freude-aktivitet. Jvf. Ronald Smelser: Robert Ley. Hitler's Labor Front Leader, New York 1988, pp. 191-216.

82. Rentschler op.cit., p.20.

83. Stephen Heath: On Screen, in Frame: Film and Ideology« in: Questions of Cinema, Indianapolis 1981, p.2. 